\title{
Presence of Vasculature Results in Faster Insulin Response in Adipocytes in Novel In Vitro Vascularized Adipose Tissue Model
}

\author{
Outi Huttala', Jertta-Riina Sarkanen 2,3, Tuula Heinonen ${ }^{1}$ and Timo Ylikomi 2,3 \\ ${ }^{1}$ FICAM, Faculty of Medicine and Health Technology, Tampere University, Tampere, Finland; ${ }^{2}$ Cell Biology, Faculty of Medicine and Health Technology, \\ Tampere University, Tampere, Finland; ${ }^{3}$ Science Centre, Pirkanmaa Hospital District, Tampere, Finland
}

\begin{abstract}
Besides being an energy store, adipose tissue is an endocrine organ closely associated with the vascular system. Human relevant in vitro models are needed to study adipose tissue and related diseases. Vasculature plays a central role in the development and inhibition of adipose tissue-related diseases.

Here, an adipocyte culture was established from hASC (human adipose stromal cells), and a vascularized adipose tissue model was established from hASC and HUVEC (human umbilical cord vein endothelial cells) co-culture, utilizing the same differentiation procedure. Comparing these models allowed analysis of the effect of vascularization on adipocytes. Both models were characterized on gene (adipocyte and vasculature-related), protein (von Willebrand factor, collagen IV, CD 140b and CD 144, secretion of leptin, adiponectin and FABP4), and functional (triglyceride accumulation, glucose uptake, and lipolysis) levels. Additionally, the vascularized adipose tissue model was exposed to chemicals with known effects on adipogenesis and angiogenesis (rosiglitazone, chlorpyrifos, prochloraz, mancozeb, butylparaben, 15-deoxy$\Delta 12$, 14-prostaglandin $\mathrm{J} 2$, bisphenol A, bis-(2-ethylhexyl) phthalate, tributyltin chloride) to compare their effects to the literature. The in vitro vascularized adipose tissue model demonstrated the presence of functional adipocytes and an extensive vascular network, displaying relevant gene and protein markers. Insulin induced glucose uptake, inhibited lipolysis, and influenced vasculature-related genes. The presence of vasculature led to a faster lipolysis inhibition by insulin and modulated responses to chemicals. This novel, thoroughly characterized, vascularized adipose tissue model is a promising new tool for studying adipose tissue as well as the effects of chemicals on adipogenesis and angiogenesis in adipose tissue.
\end{abstract}

\section{Introduction}

As obesity, both in adults and children, has reached epidemic proportions globally, the prevalence of associated diseases has increased correspondingly. In addition to type 2 diabetes, obesity and overweight are associated with cancer, sleep apnea, asthma, degenerative joint disease, hypertension, renal failure, stroke, and cardiovascular disease (Switzer et al., 2013; van Baak, 2013; Pi-Sunyer, 2009).

In addition to storing energy, adipose tissue is a dynamic endocrine organ secreting many different bioactive factors that control insulin sensitivity, energy metabolism, immune responses, and cardiovascular homeostasis ( $\mathrm{Gu}$ and $\mathrm{Xu}, 2013$; Kershaw and Flier, 2004). Adipose tissue is also one of the most vascularized tissues in the body (Cao, 2013). The vascula- ture transports oxygen, nutrients, and waste, and also produces local growth factors and cytokines that communicate with adipose tissue (Cao, 2014). In turn, adipose tissue modulates the vasculature by secreting both pro- and anti-angiogenic factors (Cao, 2014; Christiaens and Lijnen, 2010). Due to these characteristics of adipose tissue, chemicals affecting it may cause a wide variety of adverse health effects throughout the body.

A wide variety of animal models, including fruit flies, dogs, cats, pigs, rabbits, hamsters, squirrels, mice, rats, and primates, have been used to study adipose tissue (Lai et al., 2014). Although animal models contain all components of the in vivo adipose tissue, the results obtained with animal models translate poorly to humans (Lai et al., 2014; Bergen and Mersmann, 2005; Chandrasekera and Pippin, 2014), especially as the complex pathways of lipid metabolism are mostly species-specif-
Received November 27, 2018; Accepted March 13, 2019;

Epub March 14, 2019; (C) The Authors, 2019.

ALTEX 36(3), 419-434. doi:10.14573/altex.1811271

Correspondence: Outi Huttala, FICAM, Faculty of Medicine and Health Technology, Tampere University, Arvo Ylpön katu 34

33520 Tampere, Finland

(outi.huttala@tuni.fi)
This is an Open Access article distributed under the terms of the Creative Commons Attribution 4.0 International license (http://creativecommons.org/licenses/by/4.0/), which permits unrestricted use, distribution and reproduction in any medium, provided the original work is appropriately cited. 
ic (Lai et al., 2014; Bergen and Mersmann, 2005; Chandrasekera and Pippin, 2014). Thus, new human cell-based models are needed to replace animal models to support 3R principles and to offer biologically relevant tools for research of human adipose tissue-related diseases.

Adipogenic cocktail treatments, which include insulin, isobutylmethylxanthine, biotin, pantothenate, dexamethasone, and thiazolidinediones, have been problematic in developing vascularized adipose tissue as they have multiple negative effects on endothelial cells, including delayed growth (Kang et al., 2009). Volz et al. (2018) developed an elegant, serum-free defined medium for in vitro vascularized adipose tissue, but the need to pre-differentiate the adipocytes prior to combining the endothelial cells into the culture hampers its usability and lengthens the culture time.

In the present study, a novel vascularized human adipose tissue model was established. This model is based on protocols of our previously established insulin-sensitive adipocytes (Huttala et al., 2016) and vascularized adipose tissue model (Huttala et al., 2018). All these models utilize adipose tissue extract (ATE), which is a natural adipogenesis inducer that also enables angiogenesis (Sarkanen et al., 2012a). The novel vascularized adipose tissue model, established from human adipose stromal cells (hASC) and human umbilical cord vein endothelial cell (HUVEC) co-culture, was compared to adipocyte culture established from hASC, using the same differentiation procedure. The use of the same differentiation procedure for both models provides a reliable model pair to study the effect of vasculature on adipocytes. Using the vascularized adipose tissue model, the effects of chemicals on both angiogenesis and adipogenesis can be investigated simultaneously.

In order to ensure that the vascularized adipose tissue model is suitable for human adipose tissue research, it was characterized comprehensively. The gene expression of markers of adipocyte tissue and vasculature, secretion of adipokines known to be produced in in vivo white adipose tissue (leptin, FABP4, and adiponectin), accumulation of triglycerides, insulin responses (inhibition of lipolysis and induction of glucose uptake), and vascular formation were investigated. In addition, the function of the vascularized adipose tissue model was confirmed by challenging it with reference chemicals that have known effects on adipogenesis and adipose tissue angiogenesis. Nine chemicals (rosiglitazone, chlorpyrifos, prochloraz, mancozeb, butylparaben, 15-deoxy- $\Delta 12$, 14-prostaglandin J2, bisphenol A, bis-(2-ethylhexyl) phthalate, and tributyltin chloride) were used to test the adipogenic and angiogenic responses of the vascularized adipose tissue. Three of the chemicals (rosiglitazone, chlorpyrifos, and prochloraz) were employed on both the adipocyte culture and the vascularized adipose tissue model to determine the contribution of the vasculature to the chemicals' effects.

\section{Materials and methods}

\section{Ethical considerations}

This in vitro study conforms to the ethical principles outlined in the Declaration of Helsinki. Human adipose tissue samples were obtained from excess material of surgical operations, and human umbilical cords were received from caesarean sections with written informed consent at Tampere University Hospital, Tampere, Finland. The use of human adipose stromal cells (hASC) and human umbilical cord endothelial cells (HUVEC) was approved by the Ethics Committee of the Pirkanmaa Hospital District, Tampere, Finland (permit numbers: R15161 and R15033).

\section{Cells}

hASC used in the study were heterogenous cell populations obtained by isolating the stromal vascular fraction cells from human adipose tissue. HUVEC used in the study were isolated from umbilical cords. hASC and HUVEC were isolated as described by Sarkanen et al. (2012b). Before cryopreservation, all cell batches were tested for mycoplasma using Mycoplasma kit (MycoAlert ${ }^{\circledR}$ Detection Kit, Lonza Group LTD, Basel, Switzerland). Only Mycoplasma-free cell batches were used. hASC were characterized for markers CD73, CD90, and CD105 (BD biosciences, Franklin Lakes, NJ, USA) using a flow cytometer FACSCanto II (BD biosciences) as published previously (Huttala et al., 2015). hASC were expanded in hASC medium (Tab. 1) and HUVEC in Endothelial Cell Growth Medium-2 BulletKit (EGM-2, Lonza). In the co-cultures, hASC were at passage 2 and HUVEC at passage 4.

\section{Adipose tissue extract}

Adipose tissue extract (ATE) was produced as described previously (Huttala et al., 2018). Briefly, a human adipose tissue sample was manually cut into small pieces and incubated in DMEM/ F12 (Gibco, Carlsbad, CA, USA) for $24 \mathrm{~h}$ in $37^{\circ} \mathrm{C}$. The resulting extract was filtered through a $0.2 \mu \mathrm{m}$ filter. The protein content of the extract was determined with Pierce ${ }^{\mathrm{TM}}$ BCA Protein Assay Kit (Thermo Fisher Scientific, Waltham, MA, USA) according to the manufacturer's instructions using bovine serum albumin (BSA) as a standard. Results were measured after 30 min incubation at $37^{\circ} \mathrm{C}$ at $562 \mathrm{~nm}$ with Varioskan ${ }^{\mathrm{TM}}$ Flash Multimode Reader (Thermo Fisher Scientific).

\section{Vascularized adipose tissue model}

The culturing scheme of the vascularized adipose tissue model can be seen in Table 2 and the different media compositions in Table 1. The undifferentiated control contained hASC and HUVEC cells cultured in basic media corresponding to the media used for differentiation (hASC medium corresponding to ATE medium, SFM corresponding to SM and MM). The adipocyte culture and the vascularized adipose tissue model were produced using a protocol published previously as "protocol 7" (Hutta- 
Tab. 1: List of cell culture media and their components and manufacturers

\begin{tabular}{|c|c|c|c|}
\hline Medium & Abbreviation & Content & Manufacturer \\
\hline hASC medium & - & $\begin{array}{l}\text { DMEM/F12 } \\
10 \% \text { human serum } \\
2 \mathrm{mM} \text { L-glutamine }\end{array}$ & $\begin{array}{l}\text { Gibco } \\
\text { PAA laboratories } \\
\text { Gibco }\end{array}$ \\
\hline Serum free medium & SFM & $\begin{array}{l}\text { DMEM/F12 } \\
2.56 \mathrm{mM} \text { L-glutamine } \\
\text { 0.1 nM 3,3',5-triiodo-L-thyronine sodium salt } \\
\text { ITSTM Premix: } \\
-1.15 \mu \mathrm{M}: 6.65 \mu \mathrm{g} / \mathrm{ml} \text { insulin } \\
-6.65 \mu \mathrm{g} / \mathrm{ml} \text { transferrin } \\
-6.65 \mathrm{ng} / \mathrm{ml} \text { selenious acid } \\
1 \% \text { bovine serum albumin (BSA) } \\
2.8 \mathrm{mM} \text { sodium pyruvate }\end{array}$ & $\begin{array}{l}\text { Gibco } \\
\text { Gibco } \\
\text { Sigma } \\
\text { BD biosciences } \\
\\
\text { PAA laboratories } \\
\text { Gibco }\end{array}$ \\
\hline ATE medium & ATEm & $\begin{array}{l}1800 \mu \mathrm{g} / \mathrm{ml} \text { adipose tissue extract (ATE) } \\
\text { DMEM/F12 } \\
10 \% \text { human serum } \\
2 \mathrm{mM} \mathrm{L-glutamine} \\
50 \mathrm{IU} / \mathrm{ml} \text { penicillin } 50 \mu \mathrm{g} / \mathrm{ml} \text { streptomycin }\end{array}$ & $\begin{array}{l}- \\
\text { Gibco } \\
\text { PAA laboratories } \\
\text { Gibco } \\
\text { Gibco }\end{array}$ \\
\hline Stimulation medium & SM & $\begin{array}{l}\text { Serum free medium supplemented with } 200 \mu \mathrm{g} / \mathrm{ml} \\
\text { ascorbic acid } \\
0.5 \mu \mathrm{g} / \mathrm{ml} \text { heparin } \\
5.5 \mu \mathrm{M}: 2 \mu \mathrm{g} / \mathrm{ml} \text { hydrocortisone/ cortisol } \\
10 \mathrm{ng} / \mathrm{ml} \text { vascular endothelial growth factor } \\
1 \mathrm{ng} / \mathrm{ml} \text { fibroblast growth factor } \beta \\
9 \mu \mathrm{M} \text { troglitazone }\end{array}$ & $\begin{array}{l}\text { Sigma } \\
\text { Sigma } \\
\text { Sigma } \\
\text { R\&D Systems } \\
\text { R\&D Systems } \\
\text { Sigma }\end{array}$ \\
\hline $\begin{array}{l}\text { Maintenance medium } \\
\text { (stimulation medium } \\
\text { without insulin } \\
\text { and troglitazone) }\end{array}$ & MM & $\begin{array}{l}\text { DMEM/F12 } \\
2.56 \mathrm{mM} \text { L-glutamine } \\
0.1 \mathrm{nM} 3,3 \text { ',5-triiodo-L-thyronine sodium salt } \\
6.65 \mu \mathrm{g} / \mathrm{ml} \text { transferrin } \\
6.65 \mathrm{ng} / \mathrm{ml} \text { selenious acid } \\
1 \% \mathrm{BSA} \\
2.8 \mathrm{mM} \text { sodium pyruvate } \\
200 \mu \mathrm{g} / \mathrm{ml} \text { ascorbic acid } \\
0.5 \mu \mathrm{g} / \mathrm{ml} \text { heparin } \\
2 \mu \mathrm{g} / \mathrm{ml} \text { hydrocortisone } \\
10 \mathrm{ng} / \mathrm{ml} \text { VEGF } \\
1 \mathrm{ng} / \mathrm{ml} \mathrm{FGF2}\end{array}$ & $\begin{array}{l}\text { Gibco } \\
\text { Gibco } \\
\text { Sigma } \\
\text { Sigma } \\
\text { Sigma } \\
\text { PAA laboratories } \\
\text { Gibco } \\
\text { Sigma } \\
\text { Sigma } \\
\text { Sigma } \\
\text { R\&D Systems } \\
\text { R\&D Systems }\end{array}$ \\
\hline
\end{tabular}

la et al., 2016) with some modifications: one additional medium change and one additional macromolecule component (Ficoll-Paque Plus) were included. Day 0, hASC were plated in hASC medium at a density of 20,000 cells $/ \mathrm{cm}^{2}$. TrypLETM Express (Gibco) was used for the detachment of cells. On days 1, 4, 8 and 11 the medium was changed according to Table 2. Total medium volume used per well in a 48 well plate was $500 \mu 1$. After each medium change macromolecule Ficoll-Paque Plus (GE Health care, Buckinghamshire, UK) was added into each well at a volume of $25 \mu \mathrm{l}$ per $500 \mu \mathrm{l}$ of culture medium. For the vascularized adipose tissue model, the HUVEC (4400 cells $/ \mathrm{cm}^{2}$ ) were plated on day 7 by first removing $100 \mu 1$ of culture media from the wells and then adding the HUVEC in $100 \mu 1$ of EGM-2 (Lonza). Analyses were performed on day 14.

\section{Effect of chemicals on the properties and functions of} the vascularized adipose tissue model

Table 3 shows the chemicals used and their final concentrations in the test. The vascularized adipose tissue model was exposed to test chemicals on day 8 to investigate the effect of study chem- 
Tab. 2: Culture schedule for the undifferentiated control, the adipocyte culture, and the vascularized adipose tissue model

\begin{tabular}{|c|c|c|c|c|c|c|c|}
\hline Name & Day 0 & Day 1 & Day 4 & Day 7 & Day 8 & Day 11 & Day 14 \\
\hline Undifferentiated cells & \multirow{3}{*}{$\begin{array}{l}\text { hASC seeded } \\
\text { in hASC } \\
\text { medium on } \\
\text { 48-well plate: } \\
20,000 \text { cells/ } \\
\mathrm{cm}^{2}\end{array}$} & $\begin{array}{l}\text { hASC medium } \\
+25 \mu \text { l Ficoll }\end{array}$ & $\begin{array}{l}\mathrm{SFM}+25 \mu \mathrm{l} \\
\text { Ficoll }\end{array}$ & $\begin{array}{l}\text { HUVEC in } \\
\text { EGM- } 2: \\
4400 \text { cells } / \mathrm{cm}^{2}\end{array}$ & $\begin{array}{l}\mathrm{SFM}+25 \mu \mathrm{l} \\
\text { Ficoll }\end{array}$ & $\begin{array}{l}\mathrm{SFM}+25 \mu \mathrm{l} \\
\text { Ficoll }\end{array}$ & \multirow{3}{*}{ Analysis } \\
\hline Adipocyte culture & & $\begin{array}{l}\text { ATEm } \\
+25 \mu \mathrm{l} \text { Ficoll }\end{array}$ & $\begin{array}{l}\mathrm{SM}+25 \mu \mathrm{l} \\
\text { Ficoll }\end{array}$ & & $\begin{array}{l}\mathrm{SM}+25 \mu \mathrm{l} \\
\text { Ficoll }\end{array}$ & $\begin{array}{l}\mathrm{MM}+25 \mu \mathrm{l} \\
\text { Ficoll }\end{array}$ & \\
\hline $\begin{array}{l}\text { Vascularized adipose } \\
\text { tissue model }\end{array}$ & & $\begin{array}{l}\text { ATEm }+25 \mu l \\
\text { Ficoll }\end{array}$ & $\begin{array}{l}\mathrm{SM}+25 \mu \mathrm{l} \\
\text { Ficoll }\end{array}$ & $\begin{array}{l}\text { HUVEC in } \\
\text { EGM-2: } 4400 \\
\text { cells/cm² }\end{array}$ & $\begin{array}{l}\mathrm{SM}+25 \mu \mathrm{l} \\
\text { Ficoll }\end{array}$ & $\begin{array}{l}\mathrm{MM}+25 \mu \mathrm{l} \\
\text { Ficoll }\end{array}$ & \\
\hline
\end{tabular}

Tab. 3: Chemicals used in this study

\begin{tabular}{|c|c|c|c|c|c|}
\hline Chemical & $\begin{array}{l}\text { Product number/ } \\
\text { manufacturer }\end{array}$ & Purity & Concentrations tested & CAS number & Diluent \\
\hline Rosiglitazone & 71740/Cayman Chemical & $99 \%$ & $139.9 ; 44 ; 14 ; 4.4 ; 1.4 ; 0.44 ; 0.14 ; 0.044 \mu \mathrm{M}$ & $122320-73-4$ & $0.5 \%$ DMSO \\
\hline Chlorpyrifos & 45395/SIGMA & $99.7 \%$ & $100 ; 31 ; 10 ; 3.1 ; 1 ; 0.3 ; 0.1 ; 0.03 \mu \mathrm{M}$ & $2921-88-2$ & $0.5 \%$ ethanol \\
\hline Prochloraz & 45631/SIGMA & $98.6 \%$ & $5000 ; 1000 ; 500 ; 250 ; 50 ; 5 ; 0.5 ; 0.05 \mu \mathrm{M}$ & $67747-09-5$ & $0.5 \%$ ethanol \\
\hline Mancozeb & 45553/SIGMA & $97.5 \%$ & $\begin{array}{l}0.5 ; 0.16 ; 0.05 ; 0.016 ; 0.005 ; 0.0015 ; 0.0005 \\
0.00015 \mu \mathrm{g} / \mathrm{ml}\end{array}$ & $8018-01-7$ & medium \\
\hline Butylparaben & PHR1022/SIGMA & $99.7 \%$ & $500 ; 158 ; 50 ; 16 ; 5 ; 1.5 ; 0.5 ; 0.15 \mu \mathrm{g} / \mathrm{ml}$ & $94-26-8$ & medium \\
\hline $\begin{array}{l}\text { 15-Deoxy- } \Delta 12, \\
\text { 14-prostaglandin } \\
\text { J2 }\end{array}$ & D8440/SIGMA & $98.2 \%$ & $\begin{array}{l}3.15 ; 1 ; 0.315 ; 0.1 ; 0.0315 ; 0.01 ; 0.003 \\
0.001 \mu \mathrm{g} / \mathrm{ml}\end{array}$ & $87893-55-8$ & $0.5 \%$ DMSO \\
\hline Bisphenol A & 239658/SIGMA & $99.9 \%$ & $\begin{array}{l}99.4 ; 31.45 ; 9.95 ; 3.15 ; 0.5 ; 0.3 ; 0.0995 \\
0.03 \mu \mathrm{g} / \mathrm{ml}\end{array}$ & $80-05-7$ & $0.5 \%$ DMSO \\
\hline $\begin{array}{l}\text { Bis-(2-Ethylhexyl) } \\
\text { phthalate }\end{array}$ & 36735/SIGMA & $99.7 \%$ & $100 ; 31.6 ; 10 ; 31.7 ; 1 ; 0.32 ; 0.1 ; 0.0032 \mu \mathrm{g} / \mathrm{ml}$ & $117-81-7$ & $0.5 \%$ DMSO \\
\hline $\begin{array}{l}\text { Tributyltin } \\
\text { chloride }\end{array}$ & 45713/SIGMA & $97.3 \%$ & $\begin{array}{l}325.5 ; 103 ; 32.5 ; 10.3 ; 3.25 ; 1.04 ; 0.33 \\
0.11 \mathrm{ng} / \mathrm{ml}\end{array}$ & $1461-22-9$ & $0.5 \%$ DMSO \\
\hline
\end{tabular}

icals on both adipogenesis and angiogenesis. After one week of exposure, the analyses (viability/mitochondrial activity, lipid accumulation, amount of vasculature, and with three chemicals also the adipocyte-related gene expression) were performed. The actual purity of the chemicals was used in the dilution calculations. Vehicle controls for all chemicals were exposed to the same concentration of solvent that was present in the chemical dilutions.

Both the adipocyte culture and the vascularized adipose tissue model were exposed to three chemicals (rosiglitazone, chlorpyrifos, and prochloraz) on day 8 to investigate the impact of vascularization on the effects of the chemicals on adipocyte lipid accumulation and adipocyte related gene expression. The impact of chemicals on angiogenesis was also investigated. Three independent experiments with two replicates were performed.

To further evaluate the performance of the vascularized adipose tissue model, it was challenged with mancozeb, butylparaben, 15-deoxy- $\Delta 12$, 14-prostaglandin J2, bisphenol A, bis-(2-ethylhexyl) phthalate, and tributyltin chloride and their effects on lipid accumulation, viability/mitochondrial activity, and amount of vasculature were assessed. Two independent experiments with two replicates were performed. Half maximal effective concentration (EC50) values were calculated using GraphPad Prism 6.05 software.

\section{Mitochondrial activity, triglyceride accumulation, and protein secretion}

Mitochondrial activity, as an index of the number of living cells, was analyzed by WST-1 (Roche Diagnostics, Basel, Switzerland) after one-hour incubation. Absorbance was measured at $450 \mathrm{~nm}$ with a Varioskan Flash Multimode Reader (Thermo Fischer Scientific). The WST-1 results are shown without normalization to depict the cell numbers as well as mitochondrial activity.

Triglyceride accumulation in the cell cultures was measured with AdipoRed assay reagent (Lonza) after 10 min incubation at room temperature subsequent to the WST-1 analysis. Fluorescence was measured with a Varioskan Flash Multimode Reader (Thermo Fischer Scientific), with excitation at $485 \mathrm{~nm}$ and emission at $572 \mathrm{~nm}$. The amount of accumulated triglyceride per cell 
was determined by dividing AdipoRed values by WST-1 values. To calculate the amount of lipid per cell, absorbance values were first normalized to the average of the absorbance values of negative samples of each run.

Secretion of proteins, i.e., leptin, adiponectin and FABP4, was compared between the adipocyte culture and the vascularized adipose tissue model. Medium samples were analyzed with ELISA kits for adiponectin, leptin and FABP4 (cat\#DRP300, DLP00 and DFBP40, R\&D Systems, Abingdon, UK) according to the manufacturer's instructions.

\section{Glucose uptake and lipolysis}

The glucose uptake test was performed as follows: On day 14, DMEM/F12 (Gibco) was changed on the cells and incubated for $2 \mathrm{~h}$ at $37^{\circ} \mathrm{C}$ with $5 \% \mathrm{CO}_{2}$. Then cells were exposed to $100 \mathrm{nM}$ or $500 \mathrm{nM}$ insulin and incubated at $37^{\circ} \mathrm{C}$ with $5 \% \mathrm{CO}_{2}$ for $30 \mathrm{~min}$, and $\left[{ }^{3} \mathrm{H}\right]$-2-deoxy-D-glucose $(0.2 \mu \mathrm{Ci} /$ well, Perkin Elmer, Waltham, MA, USA) was added for another $20 \mathrm{~min}$. The cells were lysed using $0.1 \%$ sodium dodecyl sulfate. The radioactivity of the samples was measured by liquid scintillation counter Wallac1410 (Perkin Elmer) using OptiPhase HiSafe 2 oscillation liquid (Perkin Elmer).

Lipolysis, i.e., glycerol release, was analyzed using the EnzyChrom Adipolysis Assay Kit (BioAssay Systems, Hayward, CA, USA) according to the manufacturer's instructions. On day 14, DMEM/F12 (Gibco) was changed. After one hour, $2 \mu \mathrm{M}$ isoproterenol was added and incubated for two hours after which 100 nM or $500 \mathrm{nM}$ insulin (Sigma, Saint Louis, MO, USA) was added. After $15 \mathrm{~min}$ or $30 \mathrm{~min}$ incubation, medium was collected and fluorescence was measured with a Varioskan ${ }^{\mathrm{TM}}$ Flash Multimode Reader (Thermo Fisher Scientific) at $\mathrm{I}_{\mathrm{ex}} 530 \mathrm{~nm}$ and $\mathrm{I}_{\mathrm{em}} 585 \mathrm{~nm}$.

\section{Visualization of vasculature by immunocytochemical staining} The immunocytochemical staining was performed as described earlier (Huttala et al., 2015) except that the fixative used here was $4 \%$ formaldehyde at room temperature for $20 \mathrm{~min}$. Antibodies used were anti-von Willebrand factor IgG (produced in rabbit, Sigma), anti-collagen IV IgG (produced in mouse, Sigma), FITC-labeled goat polyclonal anti-mouse IgG (Sigma), and TRITC-labeled goat polyclonal anti-rabbit IgG (Sigma). In addition, for confocal imaging, anti-collagen IV (produced in rabbit, ab6586, Abcam, Cambridge, UK) used with secondary antibody TRITC-labeled goat polyclonal anti-rabbit IgG (Sigma), CD140b-PE (BD Biosciences, 558821), and CD144-FITC (BD Biosciences, 560411) were used. Nuclei were stained using Fluoroshield ${ }^{\mathrm{TM}}$ with DAPI mounting medium (Sigma).

\section{Microscopy and quantification of the vascular structures}

Microscopic imaging was done with a Nikon Eclipse Ti-s inverted fluorescence microscope (Nikon, Tokyo, Japan) and Nikon digital sight DS-U2-camera (Nikon), and images were further processed with NIS Elements (Nikon), ZEN 2012 software (Carl Zeiss, Oberkochen, Germany). Confocal imaging was done with LSM710 and with Zeiss Axio Observer Z1 inverted microscope
(Carl Zeiss), and images were further processed with ZEN 2012 software (Carl Zeiss). All image types were further processed using Adobe Photoshop CS3 software (Adobe Systems Incorporated, San Jose, CA, USA).

In order to investigate the area of tubular networks, cell cultures were imaged with Cell-IQ (CM Technologies Oy, Tampere, Finland) as described earlier (Huttala et al., 2018). Briefly, culture plates were imaged with a 10x objective and $5 \times 5$ grid per well. Grids were stitched together with Cell-IQ Analyzer (CM Technologies Oy) and further analyzed with ImageJ software (National Institutes of Health (NIH), Bethesda, MD, USA). Images were converted to an 8-bit gray scale, the background was subtracted and binary threshold was adjusted to determine the total tubule area in pixels. The fluorescence from adipocytes was removed from the count by size and circularity restrictions. This analysis method does not take length, number, or branch points of structures into consideration. Hence, the analysis focuses only on changes in the area covered by the vascular network.

\section{Gene expression studies}

Expression of adipose tissue-related genes Glut1, PPAR $\gamma$, leptin, Glut4, FABP4, PPAR $\alpha$, adiponectin, and PPAR $\gamma 2$ was studied as follows. Gene expression studies of insulin exposed cultures were performed by adding $500 \mu \mathrm{M}$ insulin for $24 \mathrm{~h}$ into the culture prior to RNA isolation. RNA isolation was performed using the Purelink RNA mini kit (Invitrogen, Carlsbad, CA, USA) and PCR was performed with ITaq universal SYBR green one-step kit (Biorad, Hercules, CA, USA), both according to the manufacturer's instructions. Each reaction contained $30 \mathrm{ng}$ of the template and $300 \mathrm{nM}$ primer concentration. Primer sequences and annealing temperatures are shown in Table $\mathrm{S}^{1}{ }^{1}$. A melt curve analysis was performed in each run. PCR amplification was performed with CFX96 Real-Time System (Biorad). Results were calculated with the $\Delta \Delta \mathrm{Ct}$ method $36 \mathrm{~B} 4$ as housekeeping gene. Unexposed and insulin exposed samples were analyzed using undifferentiated cells as control. The chemical exposed cultures were compared to a corresponding vehicle control.

\section{Fluidigm analysis of vessel related genes}

The developmental stage of vasculature in the model was further analyzed with a panel of 30 genes by Fluidigm system. Genes analyzed were VEGFA, VEGFR-2/FLK-1, VEGFR-1/FLT-1, FGF2, FGFR2, EGFL7, EGFR, DLL4, Notch 1, Notch 4, AGGF1, PDGF, PDGFRb, ANGPT1, ANGPT2, TIE2, Dkk1, SMO, TGFB, TGFBR1, CD34, VE-cadherin 5, GJA1, occludin, fibronectin, ITGA5, CSPG4 /NG2, S1PR1, eNOS, and HPRT. Results were produced as concentrations based on the standard curve and normalized to housekeeping gene GAPDH.

Integrity of the RNA samples was confirmed by using a 2100 Bioanalyzer (Agilent, Santa Clara, CA, USA) and the concentration of the samples was measured with a NanoDrop 1000 Spectrophotometer (Thermo Fisher Scientific). cDNA synthesis was performed using Reverse Transcriptase Master mix (Fluidigm, South San Francisco, CA, USA) according to the manufacturer's

1 doi:10.14573/altex.1811271s 
instructions on a T100 thermal cycler (Biorad). The "no template" control contained water instead of total RNA. In the "no amplification" controls, the Reverse Transcriptase Master Mix was omitted. The cDNA synthesis reaction was performed with $50 \mathrm{ng}$ of total RNA. Pre-amplification was performed using PreAmp Master Mix (Fluidigm) and the instructions provided from Fluidigm for "Fast Gene Expression Analysis Using EvaGreen" using $60^{\circ} \mathrm{C}$ as annealing temperature on a T100 thermal cycler (Biorad). Primers were designed with Primer3 software. Amplicons were designed to overlap intron sequences where possible. Amplicons were designed to be between 100-250 bp in length. Exonuclease I treatment was performed with Exonuclease I (E. coli) (Lot no 0201507, New England Biolabs, Ipswich, MA, USA) on a T100 thermal cycler (Biorad). After the exonuclease treatment, $10 \mathrm{mM}$ Tris$0.1 \mathrm{mM}$ EDTA was added to give a 10-fold dilution of the cDNA, "no template" and "no amplification" control samples.

For gene expression analysis, 96.96 Dynamic Array Chip for Gene Expression (Fluidigm) was utilized according to the manufacturer's instruction using Fluidigm IFC Controller HX (Fluidigm) and BioMark HD (Fluidigm). Sample pre-mixes were prepared by mixing 2x SsoFast EvaGreen Supermix with low ROX (Biorad), Supermix with low ROX (Biorad 172-5211), 20X DNA Binding Dye (Fluidigm 100-7609), preamplified and Exo 1-treated samples. Sample pre-mixes were then added to sample inlets of the primed 96.96 IFC. Assay mixes contained 2X Assay Loading Reagent (Fluidigm, 100-7611), 10 mM Tris-0.1 mM EDTA buffer, and $100 \mu \mathrm{M}$ forward and reverse primer mix (primer sequences Tab. S2 ${ }^{1}$ ). Assay mixes were added to assay inlets of the primed 96.96 IFC. The 96.96 IFC was then loaded to the Fluidigm Biomark HD selecting the Gene Expression, ROX, single probe, EvaGreen, and GE 96x96 PCR+Melt v1 Thermal protocol. Results were analyzed using Fluidigm's BioMark Data Collection Analysis program (version 4.1.3).

\section{Statistical analyses}

All calculations were done in Microsoft Excel 2010 (Microsoft Corporation, Redmond, WA, USA) and statistical analyses were done in GraphPad Prism (GraphPad Software Inc., La Jolla, CA, USA). Results are depicted as mean \pm standard deviation; statistical significance is expressed as *, p $<0.05$;**, $\mathrm{p}<0.01$; and $* * *, \mathrm{p}<0.001$. Results from triglyceride accumulation $(\mathrm{n}=5)$, ELISA $(n=6)$, glucose uptake $(n=5)$, lipolysis $(n=3)$, and onestep RT-qPCR $(n=6$, in insulin exposure $n=3)$ were subjected to one-way analysis of variance (ANOVA) followed by Fisher's LSD test.

\section{Results}

\subsection{The vascularized adipose tissue model shows increased secretion of adiponectin but similar lipid accumulation and secretion of leptin and FABP4 compared to the adipocyte culture}

The characteristics of the novel vascularized adipose tissue model were compared to those of adipocyte culture. Both were differentiated with a modified protocol of the previously published in vitro adipocyte model (Huttala et al., 2016). Both the adipocyte culture and the vascularized adipose tissue model contained lipid accumulating cells, which the undifferentiated cells did not contain (Fig. 1). Upon morphological inspection, the lipid accumulation in the vascularized adipose tissue model was more evenly spread out than in adipocyte culture, where there were fewer adipocytes that contained larger lipid storages. This morphology was also described in our previous study (Huttala et al., 2018) but could not be confirmed by the quantitative results of lipid per cell measurements (Fig. 1). Of the secreted proteins studied, adiponectin was significantly increased in the vascularized adipose tissue model (Fig. 1), but the secretion of leptin and FABP4 was similar in both models.

\subsection{Faster lipolysis response to insulin in the vascularized adipose tissue model}

The responses to insulin were studied in both culture models to determine the influence of the vasculature. Inhibition of lipolysis by insulin was found to be faster in the vascularized adipose tissue model, starting within $15 \mathrm{~min}$ in response to $500 \mathrm{nM}$ (Fig. 2), while it only started after $30 \mathrm{~min}$ in the adipocyte culture. Both cultures equally increased glucose uptake in response to insulin (Fig. 2).

When comparing the vascularized adipose tissue model and adipocyte culture at gene expression level, Glut1 and leptin were significantly upregulated in the vascularized adipose tissue model (Fig. 3). However, there was no difference in secreted leptin between the cultures (Fig. 1).

In gene expression analysis of the effect of insulin on both models, Glut1 was shown to be significantly down regulated in response to insulin in the vascularized adipose tissue model (Fig. 3). In addition, a trend towards an upregulation of Glut4 and FABP4 in response to insulin can be seen for both cultures. Leptin and adiponectin expression increased slightly but not significantly in the vascularized adipose tissue model in response to insulin. PPAR $\alpha$, PPAR $\gamma 2$ and general PPAR $\gamma$ expression did not respond to insulin.

\subsection{Markers of different stages of vascular formation present in vascularized adipose tissue model}

The vascularization was analyzed in the vascularized adipose tissue model with immunostaining and expression analysis of a panel of angiogenesis related genes. The gene panel was also analyzed in insulin-challenged samples. The vascular network in the vascularized adipose tissue model was well formed as seen in the collagen IV staining in Figure 4. Both CD144, i.e., ve-cadherin, and CD140b, i.e., PDGFRb, were expressed as expected in well-developed vasculature (Fig. 4). CD144 junctions are located in the tubules and CD140b on the surface of the tubules. CD140b indicates the presence of pericytes that have been shown to be present in the vascular structures previously (Huttala et al., 2015).

Gene expression results show the presence of ongoing angiogenesis as well as mature tubules (Tab. S3 ${ }^{1}$ ). The individual genes that were upregulated (2-fold or more compared to the non-insulin treated cultures) in response to insulin were PDGF, FGFR2, and ve-cadherin 5 (Tab. $\mathrm{S}^{1}{ }^{1}$ ). In the vascularized adipose tissue model prior to insulin exposure, PDGF and ve-cadherin were ex- 


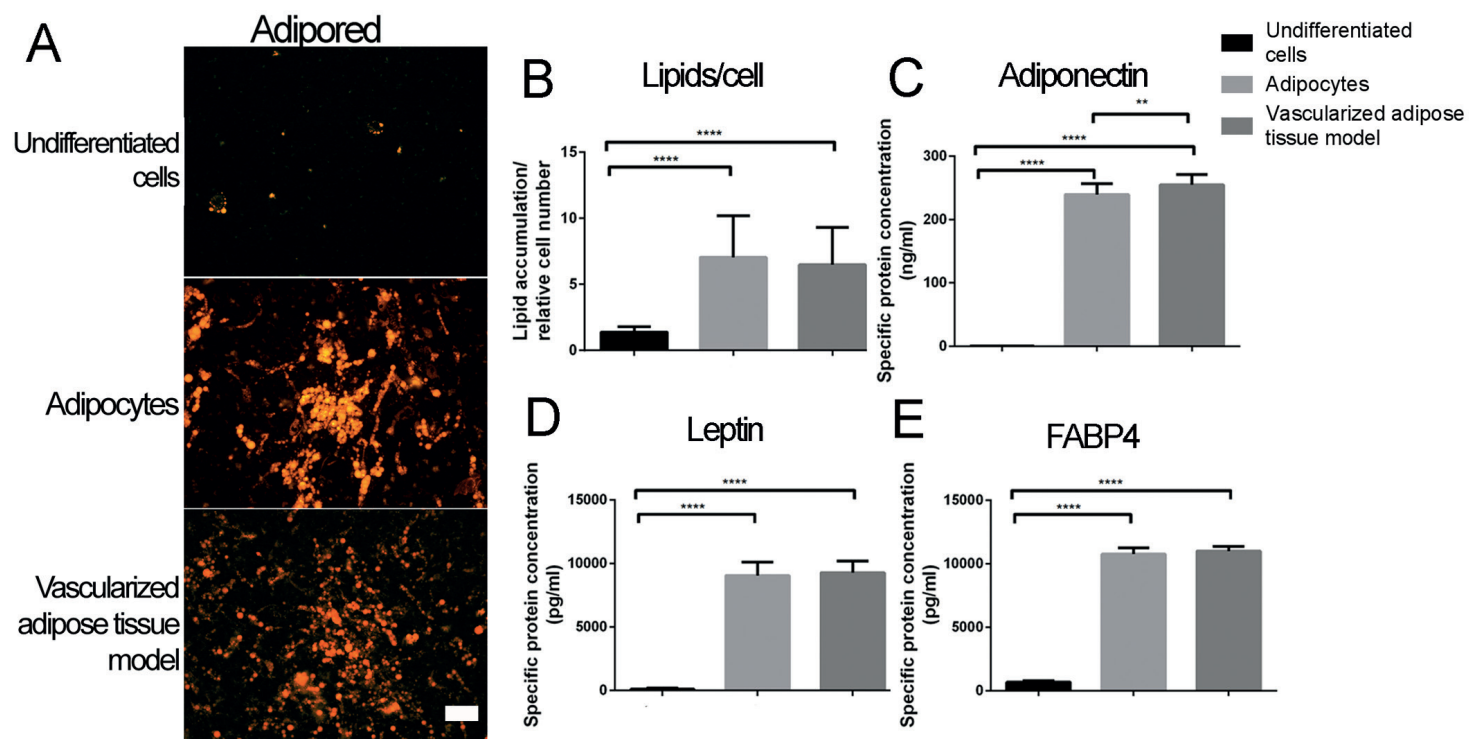

Fig. 1: Morphology, lipid accumulation and secretion of adiponectin, leptin and FABP4 in the vascularized adipose tissue model at day 14

A) Morphology of the different cultures stained with AdipoRed. Top: undifferentiated hASC-HUVEC co-culture; middle: adipocyte culture differentiated from hASC; bottom: vascularized adipose tissue model; scale bar $100 \mu \mathrm{m}$. B) Lipids accumulated per cell. Secretion of C) adiponectin, D) leptin, and E) FABP4.

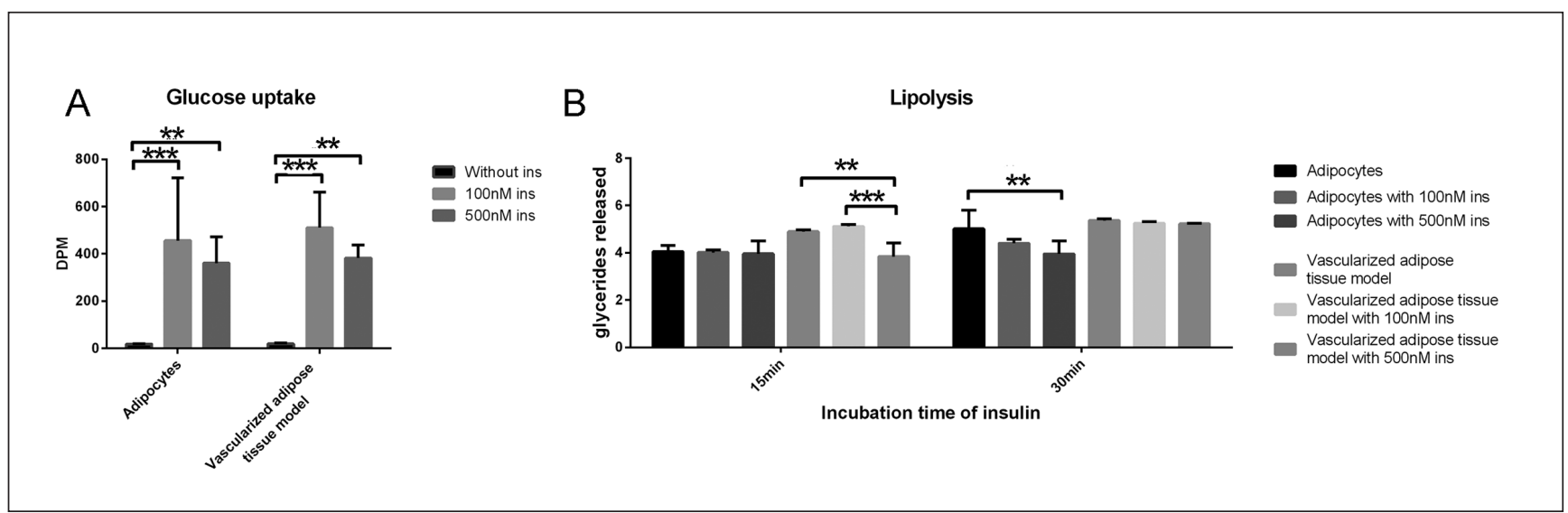

Fig. 2: Response of adipocyte culture and vascularized adipose tissue model to insulin at day 14

A) Change in glucose uptake in response to $100 \mathrm{nM}$ and $500 \mathrm{nM}$ insulin. B) Inhibition of lipolysis 15 min and 30 min after exposure to 100 and $500 \mathrm{nM}$ insulin. Ins, insulin

pressed at lower levels than the housekeeping gene. FGFR2 was already upregulated before insulin exposure.

\subsection{The effect of the adipogenesis stimulator rosiglitazone on gene expression}

Rosiglitazone was used to test the response of the vascularized adipose tissue model to adipogenesis stimulators (Fig. 5). The model was exposed to rosiglitazone for 7 days. The mitochon- drial activity/viability determined by WST-1 increased in adipocyte culture (EC50 $7.97 \mu \mathrm{M}$ ) but no effect was seen in the vascularized adipose tissue model in the tested concentration range of 0.0100-140 $\mu \mathrm{M}$. Only a slight effect of rosiglitazone was seen on lipid accumulation in both models, with lipids increasing at a higher concentration in vascularized adipose tissue model than in adipocyte culture. There was an increase in tubules in response to rosiglitazone at the lower concentrations up to $1.4 \mu \mathrm{M}$, but no 

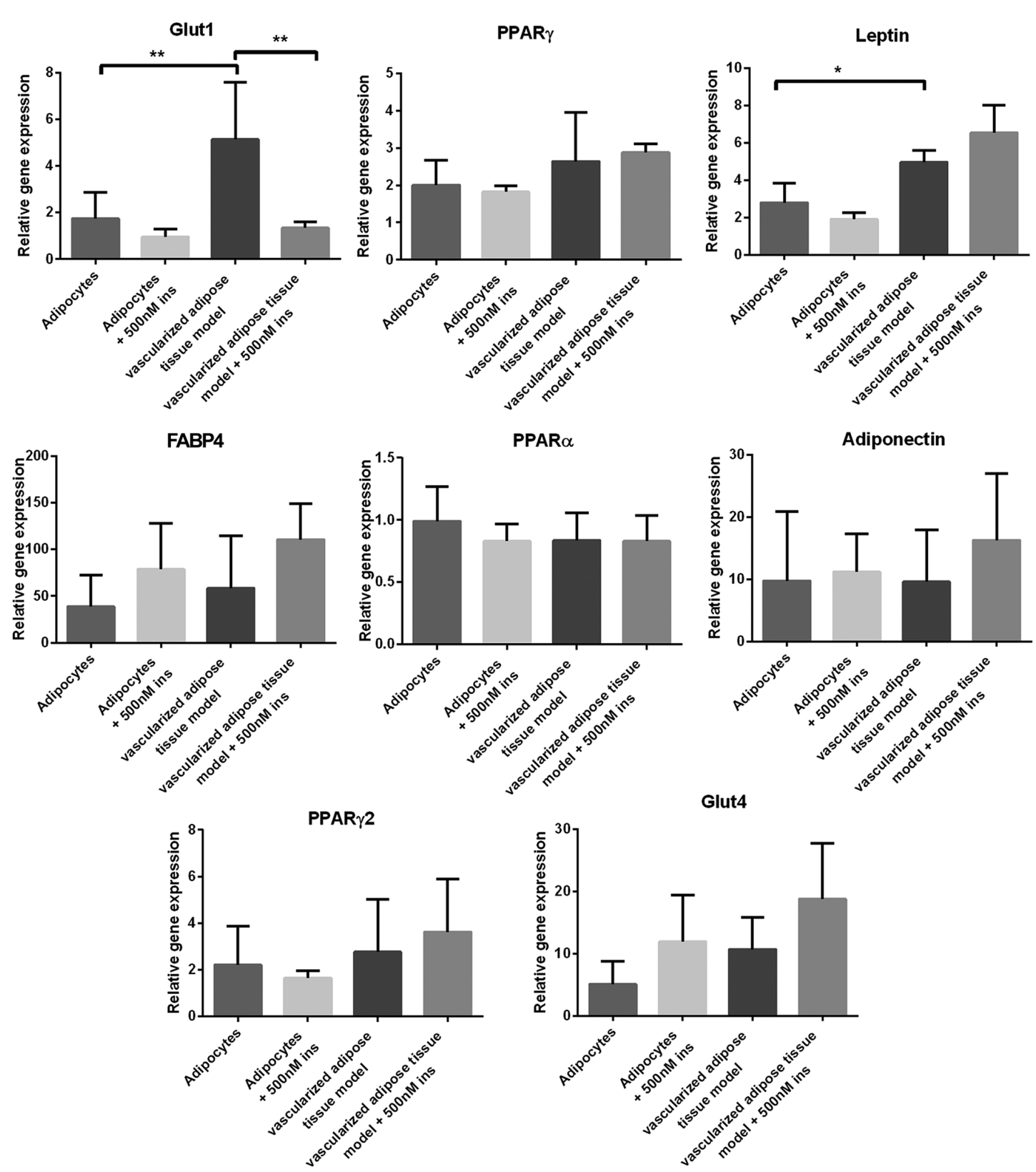

Fig. 3: Expression of adipose tissue related genes (Glut1, PPARy, leptin, Glut4, FABP4, PPARa, adiponectin, and PPARy2) with or without $500 \mathrm{nM}$ insulin in the adipocyte culture compared to the vascularized adipose tissue model at day 14 ins, insulin

statistically significant angiogenic effect was seen at the studied concentration range of $0.0100-140 \mu \mathrm{M}$. The vascular network was intact and well branched in all exposed cultures.

Gene expression of FABP4 and adiponectin greatly increased in response to $4.4 \mu \mathrm{M}$ rosiglitazone compared to the corresponding unexposed cultures in both the adipocyte culture and the vascularized adipose tissue model. Glut4 was also slightly upregulated in both cultures. The expression of leptin was increased in the vascularized adipose tissue model.

\subsection{Effects of prochloraz and chlorpyrifos on the vascularized adipose tissue model}

The effects of prochloraz and chlorpyrifos were studied in a similar manner to rosiglitazone after 7 days exposure time. Prochloraz was toxic with an EC50 of $182.2 \mu \mathrm{M}$ in adipocyte culture and 181.6 $\mu \mathrm{M}$ in the vascularized adipose tissue model (Fig. 6). Inhibition of lipid accumulation in adipocyte culture reached EC50 at $164 \mu \mathrm{M}$ and for the vascularized adipose tissue model at 187.2 $\mu \mathrm{M}$. No effect on the vasculature was observed at the tested con- 


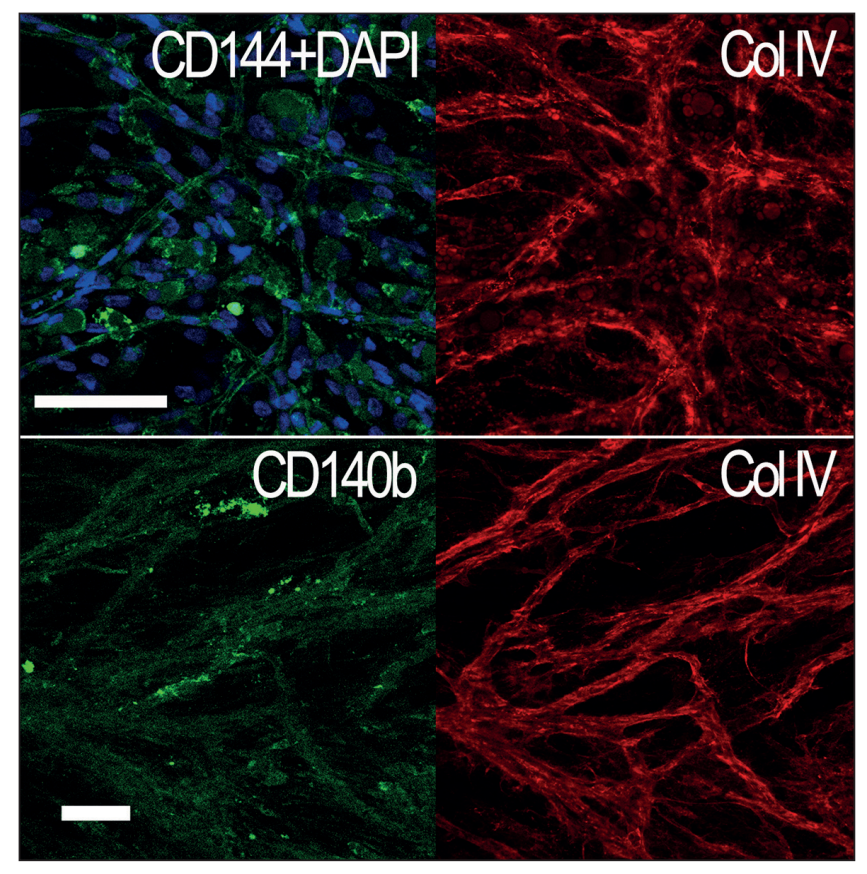

Fig. 4: Confocal images of vascularization in the vascularized adipose tissue model at day 14

Top row: CD144 (green), i.e., ve-cadherin junctions can be found in the tubules surrounded by collagen IV stained basement membrane (red). Nuclei stained with DAPI (blue). Bottom row: CD140b (green), i.e., PDGFRb staining aligns along the tubules together with collagen IV staining (red). Scale bars $100 \mu \mathrm{m}$.

\section{Rosiglitazone}
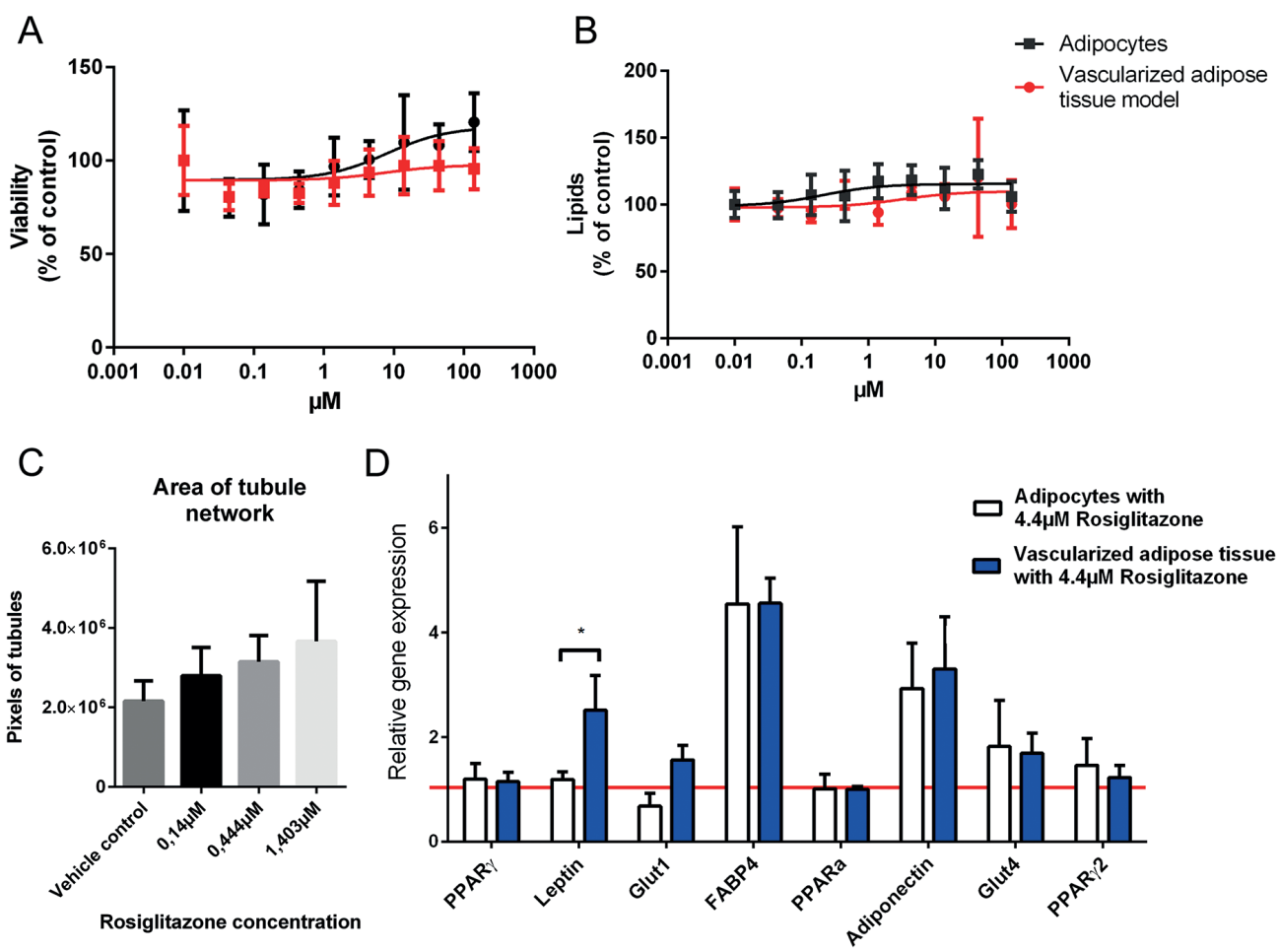

Fig. 5: Response of the adipocyte culture and the vascularized adipose tissue model to rosiglitazone

A) Mitochondrial activity/viability measured with WST-1. B) Lipid accumulation analyzed by AdipoRed. C) The area of vasculature shown for example concentrations of rosiglitazone. D) Gene expression in the adipocyte culture and the vascularized adipose tissue model after exposure to $4.4 \mu \mathrm{M}$ rosiglitazone. The red line indicates the level of unexposed corresponding cultures. 

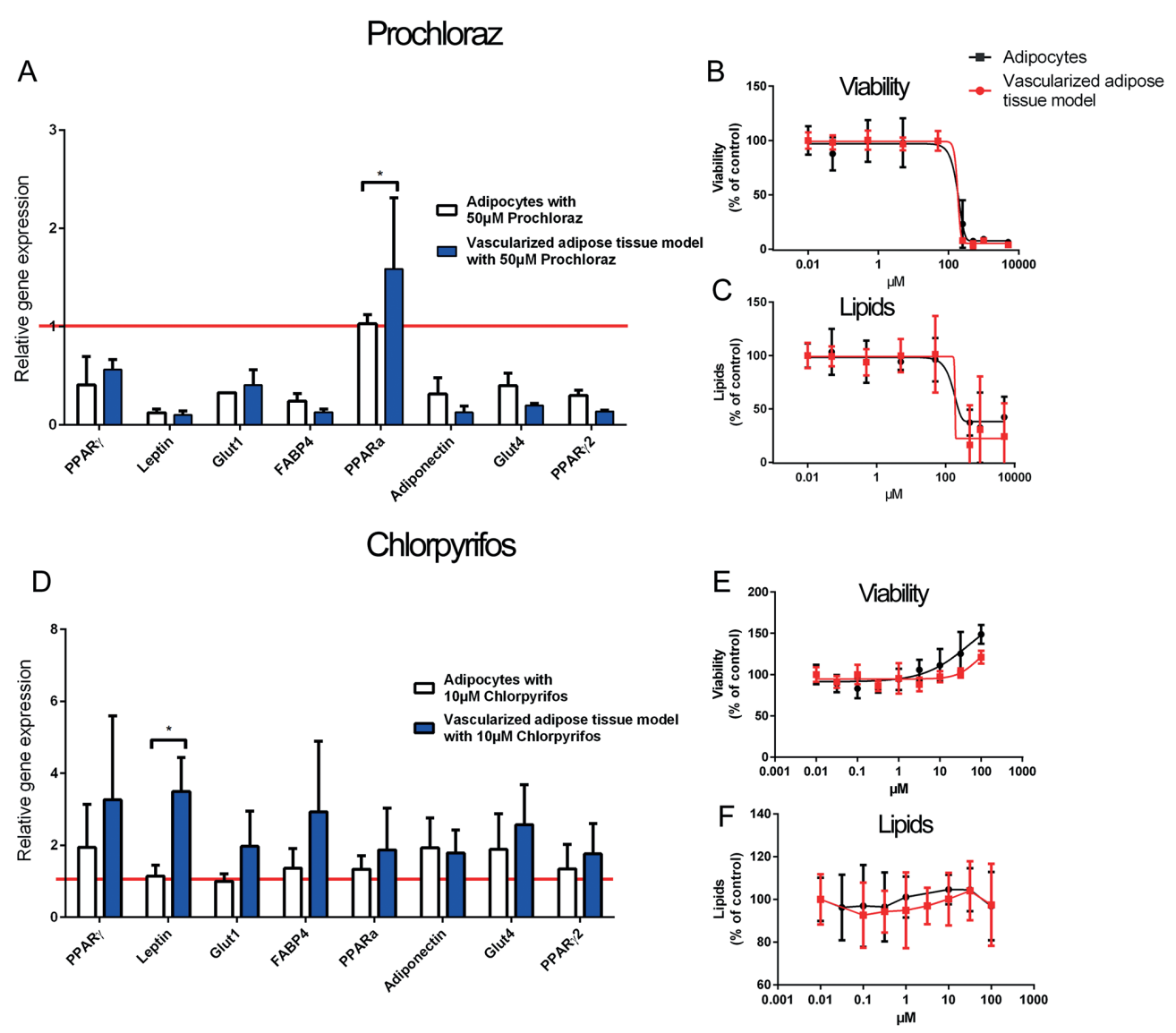

Fig. 6: Response of the adipocyte culture and the vascularized adipose tissue model to prochloraz and chlorpyrifos

A) Expression of selected genes after exposure to $50 \mu \mathrm{M}$ prochloraz. The red line indicates the level of unexposed cells. B) Mitochondrial activity/viability measured with WST-1 (EC50 of $182.2 \mu \mathrm{M}$ in the adipocyte culture and $181.6 \mu \mathrm{M}$ for the vascularized adipose tissue model). C) Lipid accumulation measured with AdipoRed (EC50 of $48.54 \mu \mathrm{M}$ for adipocyte culture and $73.51 \mu \mathrm{M}$ for vascularized adipose tissue model). D) Expression of selected genes after exposure to $10 \mu \mathrm{M}$ chlorpyrifos. Red line indicates the level of unexposed cells.

E) Mitochondrial activity/viability. F) Lipid accumulation.

Tab. 4: EC50 values for chemicals obtained in the vascularized adipose tissue model EC50, half maximal effective concentration

\begin{tabular}{|l|l|l|l|l|l|}
\hline Chemical & $\begin{array}{l}\text { EC50 } \\
\text { mitochondrial } \\
\text { activity }\end{array}$ & $\begin{array}{l}\text { Mitochondrial } \\
\text { activity (increase/ } \\
\text { decrease) }\end{array}$ & $\begin{array}{l}\text { EC50 lipid } \\
\text { accumulation }\end{array}$ & $\begin{array}{l}\text { Adipogenesis } \\
\text { (inhibitor/ } \\
\text { stimulator) }\end{array}$ & $\begin{array}{l}\text { Angiogenesis } \\
\text { (increase/decrease) }\end{array}$ \\
\hline Mancozeb & $90.24 \mu \mathrm{g} / \mathrm{ml}$ & decrease & $84.01 \mu \mathrm{g} / \mathrm{ml}$ & inhibitor & $\begin{array}{l}\text { increase at non-toxic } \\
\text { concentrations }\end{array}$ \\
\hline Butylparaben & $433.8 \mu \mathrm{g} / \mathrm{ml}$ & decrease & $340.8 \mu \mathrm{g} / \mathrm{ml}$ & inhibitor & no effect \\
\hline $\begin{array}{l}\text { 15-Deoxy- } \mathbf{1 2} \mathbf{1 4} \text {-14- } \\
\text { prostaglandin J2 }\end{array}$ & $2.675 \mu \mathrm{g} / \mathrm{ml}$ & increase & $0.1038 \mu \mathrm{g} / \mathrm{ml}$ & inhibitor & $\begin{array}{l}\text { increase at higher } \\
\text { concentrations }\end{array}$ \\
\hline $\begin{array}{l}\text { Bisphenol A } \\
\text { Bis-(2-ethylhexyl) } \\
\text { phthalate }\end{array}$ & $0.1634 \mu \mathrm{g} / \mathrm{ml}$ & decrease & $\begin{array}{l}0.03 \mu \mathrm{g} / \mathrm{ml} \text { and } \\
10 \mu \mathrm{g} / \mathrm{ml}\end{array}$ & $\begin{array}{l}\text { inhibitor } \\
\text { (biphasic effect) }\end{array}$ & $\begin{array}{l}\text { significant increase } \\
\text { concentrations }\end{array}$ \\
\hline $\begin{array}{l}\text { Tributyltin chloride } \\
\text { inhibitor }\end{array}$ & $106.2 \mathrm{ng} / \mathrm{ml}$ & increase & $312.8 \mathrm{ng} / \mathrm{ml}$ & stimulator & $\begin{array}{l}\text { inhibition at lower } \\
\text { concentrations }\end{array}$ \\
\hline
\end{tabular}


centrations of 0.01-5000 $\mu \mathrm{M}$. Exposure to $50 \mu \mathrm{M}$ prochloraz increased the expression of PPAR $\alpha$ significantly in the vascularized adipose tissue model. Other studied markers were expressed on a lower level than in the unexposed cultures.

Chlorpyrifos caused viability/mitochondrial activity to increase with an EC50 of $48.54 \mu \mathrm{M}$ for adipocyte culture and $73.51 \mu \mathrm{M}$ for the vascularized adipose tissue model (Fig. 6). Chlorpyrifos seemed to inhibit lipid accumulation at lower concentrations and increase it at the higher concentrations before inhibiting it again. No effect on the amount of vasculature was detected. Expression of leptin was significantly higher in the vascularized adipose tissue model than in adipocyte culture after exposure to $10 \mu \mathrm{M}$ chlorpyrifos.

\subsection{Results of further chemical tests}

To test further the responses of the vascularized adipose tissue model, the model was exposed to six more chemicals for 7 days. These were analyzed for lipid accumulation, mitochondrial activity, and amount of vasculature only in the vascularized adipose tissue model. Results of these chemicals can be found in Table 4. The effect on angiogenesis is determined from the changes in the total area of vasculature.

\section{Discussion}

Our previous study found two suitable methods for combining adipocytes and vascularization to produce a vascularized adipose tissue model (Huttala et al., 2018). Of these previously published methods, one was further modified here to reach a mature adipocyte marker expression profile at the end of the 14-day culture period. The vascularized adipose tissue model presented here utilized the same differentiation protocol that produced insulin responsive adipocytes (Huttala et al., 2016) with a few modifications. The differences to the previously published protocol (Huttala et al., 2016) were the additional medium change at day 8 and the addition of the macromolecule ficoll to the media. Now this differentiation protocol can be used to differentiate adipocyte culture from hASC and induce both angiogenesis and adipogenesis in a co-culture of hASC and HUVEC. This allows the comparison of the effects of vascularization in adipose tissue in for example mechanistic studies, as the only variable between the adipocyte culture and the vascularized adipose tissue model is the presence of vascularization.

This in vitro human vascularized adipose tissue model was studied at gene, protein, and functional levels, and results were compared to the adipocyte culture. Functional tests included insulin and chemical responses. The vascularized adipose tissue model was exposed to nine chemicals and their effect on lipid accumulation, mitochondrial activity/viability, and vascularization was quantified. Both models were exposed to three of these chemicals, i.e., rosiglitazone, prochloraz, and chlorpyrifos; and these cultures were also analyzed for gene expression.

The presence of the key biological characteristics confirmed that the vascularized adipose tissue model mimics the in vivo adipose tissue characteristics and functional properties well. The adipocytes in the model accumulated triglycerides and showed an upregulation of the adipocyte-related genes PPAR $\gamma$ and PPAR $\gamma 2$, adiponectin, FABP4, leptin and Glut4. Genes that are less relevant in adipocytes (Glut1 and PPAR $\alpha$ ) were not upregulated; hence the expression pattern correlates with a human white adipose tissue expression profile. The adipocytes also secreted leptin, FABP4 and adiponectin, which are also produced by native adipose tissue. The results showed that lipolysis was inhibited and glucose uptake increased in response to insulin as expected. Vascularization was seen to induce a faster lipolysis inhibition response to insulin and also had an effect on responses to chemicals. Based on these parameters, the vascularized adipose tissue model depicts the characteristics of adipose tissue well.

The importance of vascularization on adipose tissue has been shown in multiple studies. Especially the changes in vasculature in disease conditions are an important step in disease progression. Vasculature has been shown to counteract obesity and even insulin resistance when induced with VEGF (Robciuc et al., 2016; Elias et al., 2012). In our study, the results showed that adding vascularization into the model induced an upregulation of Glut1 and leptin. This is in line with an anti-obesity effect of vasculature, as the hormone leptin regulates energy balance, suppressing food intake and thereby inducing weight loss (Halaas et al., 1995). Glut1 on the other hand is a non-insulin dependent glucose transporter, which is found in a variety of tissues including fetal and adult tissues, red blood cells, endothelia and muscle (Huang et al., 2015; Ciaraldi et al., 2005; Olson and Pessin, 1996). Hence the upregulation seen here is likely due to the presence of Glut1 in the vascular endothelial cells. Angiogenic vessels are known to produce various cytokines and growth factors that promote adipogenesis (Varzaneh et al., 1994), which further enable the success of the adipogenesis process.

When developing relevant adipose tissue cell models, the source of cells is crucial. In 2016, Ruiz-Odeja et al. noted that most in vitro adipose models are still based on mouse 3T3-L1 cells (Ruiz-Ojeda et al., 2016). These are stable cell lines but not suitable when aiming for the human relevant models. For human models, one commonly utilized cell type is the human adipose stromal cell population isolated from human fat (Ruiz-Ojeda et al., 2016). These are primary, human cells as are those used in our study.

The use of primary cells has its concerns, as there is the possibility of lot-to-lot variations. When using primary cells, each isolated cell lot should be tested against quality criteria set for the cells in question. With increasing knowledge of cell type specific marker expression, more relevant quality control criteria can be defined. One recent example is the marker CD142, which can suppress adipogenesis, that has been found be expressed in hASC (Schwalie et al., 2018). Through quality control, CD142-positive cells could be purified from the population to study adipogenesis. On the other hand, the diversity of the population could be seen as an advantage, making the population more relevant for human studies.

The role of the extracellular matrix (ECM) composition has been brought up in the context of in vitro models and differentiation of stem cells. Our vascular network has been shown to produce ECM in the culture (Huttala et al., 2015) and the staining for collagen IV was positive in the current vascularized ad- 
ipose tissue model. Gene expression results (Tab. S31) showed that the vasculature contains tubules in all different developmental phases of angiogenesis, including mature vascular structures expressing PDGFRb and ANPGT1, which would indicate that the tubules also have a basal lamina layer. Due to the vast vascularization of adipose tissue, the basal membrane collagen IV is one component of natural adipose tissue ECM (Nakajima et al., 2002). As the vascularized adipose tissue model expresses a variety of angiogenesis related genes, it can be utilized to study the angiogenic potential of chemicals in addition to adipogenic properties.

The utilization of macromolecular crowding in cultures has been shown to enhance the accumulation of ECM (Zeiger et al., 2012; Chen et al., 2011). We used ficoll as a macromolecule, aided by the presence of BSA in the medium. The combination of these large molecules had a similar effect on the culture as is aimed for in the concept of macromolecular crowding. Protein concentrations of in vivo interstitial fluids could be 30-70 g/l (Bates et al., 1993) and although the concentrations used here were not high enough to lead to corresponding protein concentrations, an effect was seen in the better handling properties of the resulting model. The premature detachment issues encountered earlier (Huttala et al., 2018) no longer occur since we use ficoll. This would indicate that ECM proteins are accumulated in the cultures where they provide better attachment sites to the cells. Detachment of cells in tissue models is a serious problem when considering the applicability and reliability of the model. Detection of the possible effect of a chemical on adipogenesis and/or angiogenesis is not possible if the cells detach. Previous studies have reported that serum-free medium combined with macromolecular ficoll crowding is not beneficial for the cells (Patrikoski et al., 2017); however, we observed positive effects of ficoll in our study, probably due to the lower concentration of the crowders. Although we use human serum, serum-free medium would be beneficial as it enables defined culture conditions. Such serum-free defined medium has been developed recently and was shown to produce vascularized adipose tissue in vitro (Volz et al., 2018).

In addition to the natural composition of the in vivo environment, the stiffness of the surface on which the cells grow influences the cells. It has been shown that cells grown on low stiffness matrix are more likely to become adipocytes than cells seeded on stiffer matrices (Winer et al., 2009; Chun et al., 2006). The ECM produced by the vasculature would lead to the low stiffness platform for the adipocytes to grow on. The vascularized adipose tissue model presented here shows improvement in the expression of key adipose tissue genes compared to the previously published model (Huttala et al., 2018). The model presented here also shows secretion of the adipocyte proteins leptin, adiponectin and FABP4, which are secreted by young (few lipid vacuoles) and mature (one big lipid vacuole) adipocytes, indicating the relevance of this model in depicting mature white adipose tissue.

The interactions between tissues are important in creating in $v i$ vo-like in vitro tissue models. The influence of these interactions is seen, for example, in altered insulin responses in muscle cells caused by adipokines secreted by adipocytes (Kudoh et al., 2018). In native adipose tissue, insulin represses lipolysis in adipocytes (Choi et al., 2010) and leads to translocation of Glut4-containing vesicles from intracellular storage sites to the plasma membrane, where they dock and fuse (Bryant et al., 2002; Watson and Pessin, 2007) for glucose uptake. To ensure that central insulin responses were present in the culture, both the adipocyte culture and the vascularized adipose tissue model were exposed to insulin. Responses to insulin were confirmed by the increased uptake of glucose and inhibition of lipolysis. The lack of a further increase in glucose uptake with higher insulin concentration (Fig. 2) is most likely due to a negative feedback response to insulin hyperstimulation (Ma et al., 2013). The response time to lipolysis inhibition was found to be shorter in the vascularized adipose tissue model. As discussed above, the increase in vasculature has previously been shown to protect from insulin resistance (Robciuc et al., 2016; Elias et al., 2012) and our result of a faster response seems to support these findings. In our results (Fig. 2), the level of secreted triglycerides was slightly higher in the vascularized adipose tissue model than in the adipocytes alone, with little or no insulin addition. Robciuc et al. found that the induction of excess vasculature improved lipid metabolism and linked the activated VEGF/ VEGFR2 pathway to better insulin responses in adipose tissue and a higher basal metabolic rate (Robciuc et al., 2016). In our results, VEGFR2 is upregulated and increases in response to insulin (Tab. $\mathrm{S} 3^{1}$ ). This further supports the hypothesis that a similar mechanism of improved lipid metabolism is seen in our in vitro model and would explain the increased lipolysis when little or no insulin is present in the vascularized adipose tissue model.

At gene expression level, the exposure to insulin led to upregulation of Glut4 and FABP4 in both the adipocyte culture and the vascularized adipose tissue model. The increase of FABP4 would indicate that some adipocytes were still maturing as FABP4 is the indicator of late stage adipogenesis (Gregoire et al., 1998). Glut4 is the insulin dependent glucose transporter (Birnbaum, 1989; James et al., 1989) and hence the upregulation would be expected. In contrast, Glut1 was downregulated in the vascularized adipose tissue model. In mouse 3T3-L1 cells, Glut1 mRNA is upregulated in response to insulin (Sargeant and Paquet, 1993). It has also been shown that the expression of Glut1 in 3T3-L1 cells is downregulated as ECM rigidity decreases, whereas the Glut4 mRNA levels do not respond to the rigidity (Li et al., 2009), which would probably be closer to the situation in our vascularized adipose tissue model than the plastic rigidity. It has also been reported that there is a negative feedback loop between the expression of Glut1 and Glut4 (Ebeling et al., 1998). Also, there are studies which show no change in Glut1 expression in response to insulin (Machado et al., 1994). The response of Glut1 should be studied further to confirm the result.

In vasculature, insulin induces an upregulation of PDGF, FGFR2, and ve-cadherin (Tab. S3 ${ }^{1}$ ). Since PDGF recruits pericytes and ve-cadherin is a tight junction protein, it would seem that insulin increases the maturation of vessels. It has been shown that in retinal neovascularization a reduction of IGF-1 expression leads to an increase of the angiogenic markers angiotensin II and VEGF (Li et al., 2018). Perhaps the opposite happens with insulin exposure, as mature vessels are needed for a functioning glucose homeostasis.

In response to rosiglitazone, gene expression of FABP4, adiponectin and Glut 4 was elevated in both cultures. The expression 
of leptin was also increased in the vascularized adipose tissue model. Our vascularized adipose tissue model shows good concordance with the findings of others on the effects of rosiglitazone on adipocytes. Taxvig et al. (2012) showed that rosiglitazone increases the expression of leptin and adiponectin with no effect on PPAR $\alpha$. Rosiglitazone is also used for the induction of adipogenesis (Cheng et al., 2016; Foley et al., 2015), hence it was expected that markers of mature adipose tissue would increase. Thiazolidinediones, like rosiglitazone, are also known to enhance Glut4 action (Martinez et al., 2010). Although we did not see the increase in PPAR $\gamma$ expression or lipid accumulation described by others (Taxvig et al., 2012), the gene expression changes in our model support increased adipogenesis. It is possible that with a longer exposure time or a longer culture time after exposure (here 7 days exposure), an increased lipid accumulation would be seen. To further improve the vascularized adipose tissue model presented here, it might be possible to lower the concentration of troglitazone. Compared to our previously published adipocyte protocol (Huttala et al., 2016), we added one additional change of troglitazone medium here and this could be masking some of the lipid accumulating effects of the chemicals even though effects were seen on gene expression level. Regarding vascularization, there are studies that show an increase in adipose tissue vascularization upon in vivo exposure of humans to rosiglitazone (Gealekman et al., 2012) as well as inhibition of endothelial proliferation, migration, and angiogenesis in vitro (Sheu et al., 2006). The quantification of vascular network formed in our vascularized adipose tissue model showed an increase in angiogenesis in response to rosiglitazone, which is in concordance with the in vivo exposure data.

We found that prochloraz was equally cytotoxic in the adipocyte culture and the vascularized adipose tissue model. In the adipocyte culture, an inhibition of lipid accumulation was seen at non-cytotoxic concentrations, EC50 being $164 \mu \mathrm{M}$, however inhibition of lipid accumulation was only seen at toxic concentrations in the vascularized adipose tissue model. In the vascularized adipose tissue model, the expression of PPAR $\alpha$ increased, whereas expression of other studied markers decreased compared to the unexposed cultures. Previous results have shown that prochloraz decreases adiponectin and leptin expression and decreases lipid accumulation in 3T3-L1 adipocytes already at $50 \mu \mathrm{M}$ (Taxvig et al., 2012). Taxvig et al. did not see any effect on PPAR $\alpha$ or PPAR $\gamma$ in their study (Taxvig et al., 2012). The increased level of PPAR $\alpha$ in the vascularized adipose tissue model is an intriguing finding. The results of Taxvig et al. (2012) were obtained with a monoculture of mouse adipocytes and hence the difference may be due to the presence of vasculature. PPAR $\alpha$ is also found in endothelial cells (Bishop-Bailey and Swales, 2008) and the activation of endothelial PPAR $\alpha$ could be one reason for the upregulation seen here. However, this would likely impair angiogenesis, which was not observed by us or by others (Kleinstreuer et al., 2011). Further mechanistic studies are needed to confirm the reason for PPAR $\alpha$ upregulation.

Chlorpyrifos caused an increase in the viability/mitochondrial activity with EC50 of $48.54 \mu \mathrm{M}$ for the adipocyte culture and $73.51 \mu \mathrm{M}$ for the vascularized adipose tissue model. Chlorpyrifos seemed to inhibit lipid accumulation at lower concentrations and increased it at higher concentrations before inhibiting it again. It has been reported that chlorpyrifos decreases lipid accumulation in 3 T3 cells (Taxvig et al., 2012). In our experiments, leptin expression was significantly increased in the vascularized adipose tissue model exposed to $10 \mu \mathrm{M}$ chlorpyrifos and this effect has been shown by others on released leptin protein levels using the same concentration of chlorpyrifos (Taxvig et al., 2012). No angiogenic response to chlorpyrifos was observed in our study or reported elsewhere (Jeon et al., 2016).

The six additional studied chemicals induced various responses in the vascularized adipose tissue model. Tributyltin chloride increased lipid accumulation as reported in literature (Biemann et al., 2014; Pereira-Fernandes et al., 2013). Mancozed, which has been reported to decrease body weight (Kwon et al., 2018), inhibited lipid accumulation in our model. Bisphenol A has been shown to decrease mitochondrial activity and triglyceride accumulation (Biemann et al., 2012) in concordance with our results, although contrary results have also been reported (Ariemma et al., 2016). Based on the literature, butyl paraben (Pereira-Fernandes et al., 2014), 15-deoxy- $\Delta 12$,14-prostaglandin J2 and bis-(2-ethylhexyl) phthalate (Biemann et al., 2012) were expected to increase lipid accumulation, but the opposite was seen in our vascularized adipose tissue model.

The effects of the study chemicals were also assessed in terms of their influence on the amount of vasculature in the vascularized adipose tissue model after exposure to the chemicals. The results obtained in our model correlated well with the results reported in the literature. In addition to expected angiogenic responses observed in response to rosiglitazone, prochloraz and chlorpyrifos, the response to the following substances was also as expected based on literature: butylparaben (no effect), bisphenol A, mancozed and tributyltin. Bisphenol A has been described to induce tubule formation (Tait et al., 2015; Helmestam et al., 2014) but can also inhibit tubule formation depending on the concentration (Tait et al., 2015). In our results, an induction was seen at higher concentrations. Manconzeb has been found to influence the TIE2 pathway (Kleinstreuer et al., 2011) and in our model the effect of mancozeb was seen as a slight induction of angiogenesis. Tributyltin chloride has been shown to influence ICAM and hence the angiogenesis process (Hu et al., 2015); a slight inhibition of angiogenesis was seen in the tubule formation in our model. Based on these results, our vascularized adipose tissue model can also predict the angiogenic effects of chemicals in adipose tissue.

On the contrary, the results obtained upon challenge with bis-(2-ethylhexyl) phthalate and 15-deoxy- $\Delta 12,14$-prostaglandin $\mathrm{J} 2$ were different from those expected on the basis of literature reports. Bis-(2-ethylhexyl) phthalate has been shown to decrease PIGF and increase the soluble VEGFR-1:PlGF ratio in the fetus, which would indicate inhibition of angiogenesis (Ferguson et al., 2015); however, we found induction of angiogenesis. 15-Deoxy- $\Delta 12,14$-prostaglandin $\mathrm{J} 2$ has been reported to be an anti-angiogenic factor that induces endothelial cell apoptosis, although the mechanism remains unclear (Ho et al., 2008), but the opposite was seen in our model where higher concentrations induced angiogenesis. The effects of these two chemicals should also be studied on gene expression level to confirm the result and correlation with previous results. 


\section{Conclusion}

Due to the growing obesity problem, interest in this area with regard to safety testing of chemicals, drug development, and biomedical research, has grown. Relevant models are needed in order to conduct reliable research. The need for relevant human cell-based models is evident based on the species differences. In vitro human cell models that are confirmed to be relevant and which are thoroughly characterized can provide the most relevant results. The vascularized adipose tissue model developed here is a valuable research model as it is a relevant replacement option for animal models used for adipose tissue research.

The vascularized adipose tissue model presented here contains a well-formed extensive vascular network and mature adipocytes, analyzed on gene and protein level, and shows robust responses to insulin. The response of adipocytes to insulin is faster in the presence of vasculature. This finding should be studied further as it might lead to the development of new therapeutic strategies to treat insulin resistance. This novel vascularized adipose tissue model is relevant for studying adipose tissue, especially the interaction of vasculature and adipocytes, and for studying effects of chemicals on adipogenesis and adipose tissue angiogenesis.

\section{References}

Ariemma, F., D’Esposito, V., Liguoro, D. et al. (2016). Low-dose bisphenol-A impairs adipogenesis and generates dysfunctional 3T3-L1 adipocytes. PLoS One 11, e0150762. doi:10.1371/ journal.pone.0150762

Bates, D. O., Levick, J. R. and Mortimer, P. S. (1993). Change in macromolecular composition of interstitial fluid from swollen arms after breast cancer treatment, and its implications. Clin Sci (Lond) 85, 737-746. doi:10.1042/cs0850737

Bergen, W. G. and Mersmann, H. J. (2005). Comparative aspects of lipid metabolism: Impact on contemporary research and use of animal models. J Nutr 135, 2499-2502. doi:10.1093/jn/ 135.11.2499

Biemann, R., Navarrete Santos, A., Navarrete Santos, A. et al. (2012). Endocrine disrupting chemicals affect the adipogenic differentiation of mesenchymal stem cells in distinct ontogenetic windows. Biochem Biophys Res Commun 417, 747-752. doi:10.1016/j.bbrc.2011.12.028

Biemann, R., Fischer, B., Bluher, M. and Navarrete Santos, A. (2014). Tributyltin affects adipogenic cell fate commitment in mesenchymal stem cells by a PPARgamma independent mechanism. Chem Biol Interact 214, 1-9. doi:10.1016/j. cbi.2014.01.021

Birnbaum, M. J. (1989). Identification of a novel gene encoding an insulin-responsive glucose transporter protein. Cell 57, 305-315. doi:10.1016/0092-8674(89)90968-9

Bishop-Bailey, D. and Swales, K. E. (2008). The role of PPARs in the endothelium: Implications for cancer therapy. PPAR Res 2008, 904251. doi:10.1155/2008/904251

Bryant, N. J., Govers, R. and James, D. E. (2002). Regulated transport of the glucose transporter GLUT4. Nat Rev Mol Cell Biol 3, 267-277. doi:10.1038/nrm782
Cao, Y. (2013). Angiogenesis and vascular functions in modulation of obesity, adipose metabolism, and insulin sensitivity. Cell Metab 18, 478-489. doi:10.1016/j.cmet.2013.08.008

Cao, Y. (2014). Angiogenesis as a therapeutic target for obesity and metabolic diseases. Chem Immunol Allergy 99, 170-179. doi:10.1159/000353254

Chandrasekera, P. C. and Pippin, J. J. (2014). Of rodents and men: Species-specific glucose regulation and type 2 diabetes research. ALTEX 31, 157-176. doi:10.14573/altex.1309231

Chen, C., Loe, F., Blocki, A. et al. (2011). Applying macromolecular crowding to enhance extracellular matrix deposition and its remodeling in vitro for tissue engineering and cell-based therapies. Adv Drug Deliv Rev 63, 277-290. doi:10.1016/j. addr.2011.03.003

Cheng, B., Wu, M., Xu, S. et al. (2016). Cocktail supplement with rosiglitazone: A novel inducer for chicken preadipocyte differentiation in vitro. Biosci Rep 36, 1-11. doi:10.1042/ BSR20160049

Choi, S. M., Tucker, D. F., Gross, D. N. et al. (2010). Insulin regulates adipocyte lipolysis via an Akt-independent signaling pathway. Mol Cell Biol 30, 5009-5020. doi:10.1128/ MCB.00797-10

Christiaens, V. and Lijnen, H. R. (2010). Angiogenesis and development of adipose tissue. Mol Cell Endocrinol 318, 2-9. doi:10.1016/j.mce.2009.08.006

Chun, T. H., Hotary, K. B., Sabeh, F. et al. (2006). A pericellular collagenase directs the 3-dimensional development of white adipose tissue. Cell 125, 577-591. doi:10.1016/j.cell. 2006.02.050

Ciaraldi, T. P., Mudaliar, S., Barzin, A. et al. (2005). Skeletal muscle GLUT1 transporter protein expression and basal leg glucose uptake are reduced in type 2 diabetes. J Clin Endocrinol Metab 90, 352-358. doi:10.1210/jc.2004-0516

Ebeling, P., Koistinen, H. A. and Koivisto, V. A. (1998). Insulin-independent glucose transport regulates insulin sensitivity. FEBS Lett 436, 301-303. doi:10.1016/S0014-5793(98) 01149-1

Elias, I., Franckhauser, S., Ferre, T. et al. (2012). Adipose tissue overexpression of vascular endothelial growth factor protects against diet-induced obesity and insulin resistance. Diabetes 61, 1801-1813. doi:10.2337/db11-0832

Ferguson, K. K., McElrath, T. F., Cantonwine, D. E. et al. (2015). Phthalate metabolites and bisphenol-A in association with circulating angiogenic biomarkers across pregnancy. Placenta 36, 699-703. doi:10.1016/j.placenta.2015.04.002

Foley, B., Clewell, R. and Deisenroth, C. (2015). Development of a human adipose-derived stem cell model for characterization of chemical modulation of adipogenesis. Appl In Vitro Toxicol 1, 66-78. doi:10.1089/aivt.2014.0007

Gealekman, O., Guseva, N., Gurav, K. et al. (2012). Effect of rosiglitazone on capillary density and angiogenesis in adipose tissue of normoglycaemic humans in a randomised controlled trial. Diabetologia 55, 2794-2799. doi:10.1007/s00125-0122658-2

Gregoire, F. M., Smas, C. M. and Sul, H. S. (1998). Understanding adipocyte differentiation. Physiol Rev 78, 783-809. doi:10.1152/physrev.1998.78.3.783 
$\mathrm{Gu}, \mathrm{P}$. and $\mathrm{Xu}, \mathrm{A}$. (2013). Interplay between adipose tissue and blood vessels in obesity and vascular dysfunction. Rev Endocr Metab Disord 14, 49-58. doi:10.1007/s11154-012-9230-8

Halaas, J. L., Gajiwala, K. S., Maffei, M. et al. (1995). Weightreducing effects of the plasma protein encoded by the obese gene. Science 269, 543-546. doi:10.1126/science.7624777

Helmestam, M., Davey, E., Stavreus-Evers, A. and Olovsson, M. (2014). Bisphenol A affects human endometrial endothelial cell angiogenic activity in vitro. Reprod Toxicol 46, 69-76. doi:10.1016/j.reprotox.2014.03.002

Ho, T. C., Chen, S. L., Yang, Y. C. et al. (2008). 15-deoxy-Delta(12,14)-prostaglandin $\mathrm{J} 2$ induces vascular endothelial cell apoptosis through the sequential activation of MAPKS and p53. J Biol Chem 283, 30273-30288. doi:10.1074/jbc. M804196200

Hu, Z., Brooks, S. A., Dormoy, V. et al. (2015). Assessing the carcinogenic potential of low-dose exposures to chemical mixtures in the environment: Focus on the cancer hallmark of tumor angiogenesis. Carcinogenesis 36, Suppl 1, S184-202. doi:10.1093/carcin/bgv036

Huang, L., Nakayama, H., Klagsbrun, M. et al. (2015). Glucose transporter 1-positive endothelial cells in infantile hemangioma exhibit features of facultative stem cells. Stem Cells 33, 133-145. doi:10.1002/stem.1841

Huttala, O., Vuorenpaa, H., Toimela, T. et al. (2015). Human vascular model with defined stimulation medium - A characterization study. ALTEX 32, 125-136. doi:10.14573/ altex. 1411271

Huttala, O., Mysore, R., Sarkanen, J. R. et al. (2016). Differentiation of human adipose stromal cells in vitro into insulin-sensitive adipocytes. Cell Tissue Res 366, 63-74. doi:10.1007/ s00441-016-2409-7

Huttala, O., Palmroth, M., Hemminki, P. et al. (2018). Development of versatile human in vitro vascularized adipose tissue model with serum-free angiogenesis and natural adipogenesis induction. Basic Clin Pharmacol Toxicol 123, 62-71. doi:10.1111/bcpt.12987

James, D. E., Strube, M. and Mueckler, M. (1989). Molecular cloning and characterization of an insulin-regulatable glucose transporter. Nature 338, 83-87. doi:10.1038/338083a0

Jeon, H. J., Lee, Y. H., Kim, M. J. et al. (2016). Integrated biomarkers induced by chlorpyrifos in two different life stages of zebrafish (Danio rerio) for environmental risk assessment. Environ Toxicol Pharmacol 43, 166-174. doi:10.1016/j. etap.2016.03.010

Kang, J. H., Gimble, J. M. and Kaplan, D. L. (2009). In vitro 3D model for human vascularized adipose tissue. Tissue Eng Part A 15, 2227-2236. doi:10.1089/ten.tea.2008.0469

Kershaw, E. E. and Flier, J. S. (2004). Adipose tissue as an endocrine organ. J Clin Endocrinol Metab 89, 2548-2556. doi:10.1210/jc.2004-0395

Kleinstreuer, N. C., Judson, R. S., Reif, D. M. et al. (2011). Environmental impact on vascular development predicted by high-throughput screening. Environ Health Perspect 119, 1596-1603. doi:10.1289/ehp.1103412

Kudoh, A., Satoh, H., Hirai, H. et al. (2018). Preliminary evidence for adipocytokine signals in skeletal muscle glucose uptake. Front Endocrinol (Lausanne) 9, 295. doi:10.3389/ fendo.2018.00295

Kwon, D., Chung, H., Shin, W. et al. (2018). Toxicological evaluation of dithiocarbamate fungicide mancozeb on the endocrine functions in male rats. Mol Cell Toxicol 14, 105-112. doi:10.1007/s13273-018-0013-5

Lai, M., Chandrasekera, P. C. and Barnard, N. D. (2014). You are what you eat, or are you? The challenges of translating highfat-fed rodents to human obesity and diabetes. Nutr Diabetes 4, e135. doi:10.1038/nutd.2014.30

Li, F., Liu, Y., Ren, L. et al. (2018). IGF-1 regulates Ang II and VEGF signaling pathways in retinal neovascularization. Eur Rev Med Pharmacol Sci 22, 6175-6180. doi:10.26355/ eurrev_201810_16022

Li, Q., Hosaka, T., Jambaldorj, B. et al. (2009). Extracellular matrix with the rigidity of adipose tissue helps 3T3-L1 adipocytes maintain insulin responsiveness. $J$ Med Invest 56, 142149. doi:10.2152/jmi.56.142

Ma, J., Nakagawa, Y., Kojima, I. and Shibata, H. (2013). Prolonged insulin stimulation down-regulates GLUT4 through oxidative stress-mediated retromer inhibition by a protein kinase CK2-dependent mechanism in 3T3-L1 adipocytes. J Biol Chem 289, 133-142. doi:10.1074/jbc.M113.533240

Machado, U. F., Shimizu, I. and Saito, M. (1994). Reduced content and preserved translocation of glucose transporter (GLUT 4) in white adipose tissue of obese mice. Physiol Behav 55, 621-625. doi:10.1016/0031-9384(94)90035-3

Martinez, L., Berenguer, M., Bruce, M. C. et al. (2010). Rosiglitazone increases cell surface GLUT4 levels in 3T3-L1 adipocytes through an enhancement of endosomal recycling. Biochem Pharmacol 79, 1300-1309. doi:10.1016/j. bcp.2009.12.013

Nakajima, I., Muroya, S., Tanabe, R. and Chikuni, K. (2002). Positive effect of collagen V and VI on triglyceride accumulation during differentiation in cultures of bovine intramuscular adipocytes. Differentiation 70, 84-91. doi:10.1046/j.14320436.2002.700203.x

Olson, A. L. and Pessin, J. E. (1996). Structure, function, and regulation of the mammalian facilitative glucose transporter gene family. Annu Rev Nutr 16, 235-256. doi:10.1146/ annurev.nu.16.070196.001315

Patrikoski, M., Lee, M. H. C., Makinen, L. et al. (2017). Effects of macromolecular crowding on human adipose stem cell culture in fetal bovine serum, human serum, and defined xeno-free/serum-free conditions. Stem Cells Int 2017, 6909163. doi:10.1155/2017/6909163

Pereira-Fernandes, A., Vanparys, C., Hectors, T. L. et al. (2013). Unraveling the mode of action of an obesogen: Mechanistic analysis of the model obesogen tributyltin in the 3T3-L1 cell line. Mol Cell Endocrinol 370, 52-64. doi:10.1016/j. mce.2013.02.011

Pereira-Fernandes, A., Vanparys, C., Vergauwen, L. et al. (2014). Toxicogenomics in the 3T3-L1 cell line, a new approach for screening of obesogenic compounds. Toxicol Sci 140, 352363. doi:10.1093/toxsci/kfu092

Pi-Sunyer, X. (2009). The medical risks of obesity. Postgrad Med 121, 21-33. doi:10.3810/pgm.2009.11.2074 
Robciuc, M. R., Kivela, R., Williams, I. M. et al. (2016). VEGFB/VEGFR1-induced expansion of adipose vasculature counteracts obesity and related metabolic complications. Cell Metab 23, 712-724. doi:10.1016/j.cmet.2016.03.004

Ruiz-Ojeda, F. J., Ruperez, A. I., Gomez-Llorente, C. et al. (2016). Cell models and their application for studying adipogenic differentiation in relation to obesity: A review. Int $J \mathrm{Mol}$ Sci 17, 1040. doi:10.3390/ijms 17071040

Sargeant, R. J. and Paquet, M. R. (1993). Effect of insulin on the rates of synthesis and degradation of GLUT1 and GLUT4 glucose transporters in 3T3-L1 adipocytes. Biochem J 290, 913919. doi:10.1042/bj2900913

Sarkanen, J. R., Kaila, V., Mannerstrom, B. et al. (2012a). Human adipose tissue extract induces angiogenesis and adipogenesis in vitro. Tissue Eng Part A 18, 17-25. doi:10.1089/ten. TEA.2010.0712

Sarkanen, J. R., Vuorenpaa, H., Huttala, O. et al. (2012b). Adipose stromal cell tubule network model provides a versatile tool for vascular research and tissue engineering. Cells Tissues Organs 196, 385-397. doi:10.1159/000336679

Schwalie, P. C., Dong, H., Zachara, M. et al. (2018). A stromal cell population that inhibits adipogenesis in mammalian fat depots. Nature 559, 103-108. doi:10.1038/s41586-018-0226-8

Sheu, W. H., Ou, H. C., Chou, F. P. et al. (2006). Rosiglitazone inhibits endothelial proliferation and angiogenesis. Life Sci 78, 1520-1528. doi:10.1016/j.lfs.2005.07.046

Switzer, N. J., Mangat, H. S. and Karmali, S. (2013). Current trends in obesity: Body composition assessment, weight regulation, and emerging techniques in managing severe obesity. J Interv Gastroenterol 3, 34-36. doi:10.1111/vaa.12219

Tait, S., Tassinari, R., Maranghi, F. and Mantovani, A. (2015). Bisphenol A affects placental layers morphology and angiogenesis during early pregnancy phase in mice. J Appl Toxicol 35, 1278-1291. doi:10.1002/jat.3176

Taxvig, C., Dreisig, K., Boberg, J. et al. (2012). Differential effects of environmental chemicals and food contaminants on adipogenesis, biomarker release and PPARgamma activation. Mol Cell Endocrinol 361, 106-115. doi:10.1016/j. mce.2012.03.021

van Baak, M. A. (2013). Nutrition as a link between obesity and cardiovascular disease: How can we stop the obesity epidemic? Thromb Haemost 110, 689-696. doi:10.1160/TH13-010045
Varzaneh, F. E., Shillabeer, G., Wong, K. L. and Lau, D. C. (1994). Extracellular matrix components secreted by microvascular endothelial cells stimulate preadipocyte differentiation in vitro. Metabolism 43, 906-912. doi:00260495(94)90275-5

Volz, A. C., Hack, L., Atzinger, F. B. and Kluger, P. J. (2018). Completely defined co-culture of adipogenic differentiated ASCs and microvascular endothelial cells. ALTEX 35, 464476. doi:10.14573/altex.1802191

Watson, R. T. and Pessin, J. E. (2007). GLUT4 translocation: The last 200 nanometers. Cell Signal 19, 2209-2217. doi:10.1016/j.cellsig.2007.06.003

Winer, J. P., Janmey, P. A., McCormick, M. E. and Funaki, M. (2009). Bone marrow-derived human mesenchymal stem cells become quiescent on soft substrates but remain responsive to chemical or mechanical stimuli. Tissue Eng Part A 15, 147154. doi:10.1089/ten.tea.2007.0388

Zeiger, A. S., Loe, F. C., Li, R. et al. (2012). Macromolecular crowding directs extracellular matrix organization and mesenchymal stem cell behavior. PLoS One 7, e37904. doi:10.1371/ journal.pone.0037904

\section{Conflict of interest}

Patent issued in USA (9056084B2), pending elsewhere (WO2010026299A1).

\section{Acknowledgements}

We thank the staff and donors at Tampere University Hospital for collaboration concerning donation of adipose tissue and umbilical cord samples. At the University of Tampere, we want to thank Ms Sari Leinonen, Ms Mirja Hyppönen, Ms Paula Helpiölä, Ms Maaret Vaani and Ms Hilkka Mäkinen for their excellent technical assistance. We would also like to thank Biomedicum Functional Genomics Unit (FuGU) at the University of Helsinki, especially Hanna Ala-Hongisto, for providing the Fluidigm analysis as a service. Funding for the project was provided by The Diabetes Research Foundation, Finnish Funding Agency for Technology and Innovation, and City of Tampere Science Foundation. 